\title{
Does crop diversity contribute to dietary diversity? Evidence from integration of vegetables into maize-based farming systems
}

\author{
Srinivasulu Rajendran ${ }^{1 *} \mathbb{D}$, Victor Afari-Sefa ${ }^{2} \mathbb{D}$, Apurba Shee ${ }^{3}$, Temesgen Bocher ${ }^{4}$, Mateete Bekunda ${ }^{5}$, \\ Inviolate dominick ${ }^{6}$ and Philipo Joseph Lukumay ${ }^{6}$
}

\begin{abstract}
Background: Maize is the most important staple crop for food security and livelihood of smallholder farmers in many parts of sub-Saharan Africa, but it alone cannot ensure food security. Cropping patterns must be diversified to ensure an adequate supply and economic access to greater variety of foods for smallholder farm households. This study measured the effect of crop diversification on household dietary diversity in a selected study locale using a survey of 300 randomly stratified farm households in 10 villages located in the Babati, Kongwa and Kiteto districts of Tanzania.

Results: Based on multiple regression analysis, the study found that simply increasing Simpson's Index does not influence dietary diversity of farm households due to the presence of interaction effect between Simpson's Index and crop income. It is much more critical and significant to increase the revenue generated from diversified crops along with other socioeconomic endowment and behavioral characteristics of farm households. This is particularly applicable to poorer smallholder farmers who receive crop income less than US\$85 per sales transaction and per season. Particularly, marginal and smallholders might be exposed to the effects of crop diversification and crop income toward increasing in their household dietary diversity score.
\end{abstract}

Conclusion: Under average crop income scenarios, households that diversify their crop production tend to increase their dietary diversity from their existing dietary diversity score at a decreasing rate. However, under below average crop income threshold scenarios, farmers tend to increase their dietary diversity score from their existing score at an increasing rate when they diversify into high-value crops that attract relatively high farm gate values and accrue higher net revenues from the market. Monthly food expenditure also tends to positively influence household dietary diversity, indicating that farm households that spend more on market-purchased food have consistent increases in the their dietary diversity scores at the household level. This study concludes that improving economic access to variety of foods at the smallholder household level by diversifying diets through increased crop diversification should be encouraged within maize-based farming systems of the study locale, through integration of micronutrient-rich foods such as vegetables.

\section{Background}

Lack of economic access to diverse and nutritional food is undoubtedly the major cause of malnutrition in subSaharan Africa (for example, [2, 17, 19, 34-36, 41, 57, 65]). Imbalanced diets, mainly resulting from excessive

\footnotetext{
*Correspondence: srini.rajendran@cgiar.org

${ }^{1}$ International Potato Center (CIP), Sub-Saharan Africa (SSA) Regional

Office, ILRI Campus, Nairobi, Kenya

Full list of author information is available at the end of the article
}

consumption of carbohydrates, also contribute to labor productivity losses $[8,32,64]$, reduced educational attainment and income [3]. In Tanzania, most rural and urban households, particularly those in the low-income group, consume mainly staples, which are high in carbohydrates, but low in minerals and vitamins [38]. Consuming staple food items might increase energy availability, but will not improve nutritional outcomes if not consumed in conjunction with micronutrient-rich foods [26, 37]. Farmers 
engaged in the production and marketing of staple food items may ultimately improve household income, but not necessarily achieve a direct proportionate reduction in malnutrition. Nonetheless, higher household incomes have been found to improve nutritional outcomes, but at a much slower rate $[16,49]$.

Vegetables in general, and traditional vegetables in particular, are rich in micronutrients and other healthpromoting phytochemicals; nutrient-dense vegetables complement staple foods and improve nutritional quality of diets $[25,33,46,65,67]$. Integrating micronutrientrich foods such as vegetables, fruits and some animal products into diets has been found to be one of the most practical and sustainable ways to alleviate micronutrient deficiency, through increased dietary diversity [5]. Consumption of diverse vegetables significantly improves nutrition [51] through access to diverse mineral, micronutrient and vitamin-rich products [24, 62].

Integrating vegetables into maize-based farming systems as a means to augment household income is appropriate due to their high farm gate values per unit land and economic access to diverse food groups [7]. More diverse production systems may contribute to more diverse household diets for farming communities [12]. Reducing the prevalence of micronutrient deficiencies will not be sustainable if food consumption is not diversified [31, 61]. Dietary diversity is an important means to measure the nutritional status of target populations consuming diversified and quality diets $[2,21,22,25,32,36,37,50$, 59]. Dietary diversity could also be a useful indicator of nutrition security [25], but additional research is needed to validate and test alternative indicators for different purposes.

A large body of literature has analyzed the association between individual dietary diversity and child growth and other nutrition indicators (for example, $[6,14,30$, $49,13])$. The conclusion from these studies is that there is a strong association between child dietary diversity and nutritional status after controlling for relevant socioeconomic characteristics of households. The authors argued that dietary diversity serves as a proxy for determining diet quality, and hence, individual dietary diversity can be used as an indicator of diet quality.

Some studies have shown that an increase in household dietary diversity is associated with higher socioeconomic status and household food security measured in terms of household food energy availability $([1,12,15$, $23,27,39,43,45,58,20])$. Household dietary diversity is also associated with monthly per capita calorie availability from non-staples for all households [23] and household expenditure which is a proxy for household wealth and well-being [58]. It can be considered as an indicator for measuring food security [23]. Consequently, FAO [18] argues that there are two types of dietary diversity, namely household dietary diversity and individual dietary diversity. Household dietary diversity is an indication of household economic access to food, whereas individual dietary diversity is a reflection of the nutritional quality of diets consumed by a household member.

More recently, a few studies (for example, [12, 47, 55, 57]) have attempted to establish a linkage between land use or cropping pattern and dietary diversity of households as well as the contribution of biodiversity to dietary diversity [10]. In this light, Jones et al. [27] examined the relationship between farm diversity and dietary diversity among households and concluded that there is a strong relationship between dietary diversity and farm diversity in Malawi based on a national representative sample survey implemented from March 2010 to March 2011 as part of a World Bank Living Standards Assessment study. Another most recent study by Smale et al. [56] examined the association between hybrid seed use and four indicators of dietary diversity using the food group diversity (24-h recall period), vitamin A diversity (7-day recall period), food frequency (7-day recall period) and frequency of consuming foods fortified with vitamin A (7-day recall period) approaches based on a primary survey of 1128 households in Zambia.

In this paper, we focus on the food group diversity approach based on a 24-h recall period. Herforth [22] specifically examined these relationships in the context of Tanzania and Kenya. The author concluded that crop diversity was significantly associated with household dietary diversity and also was more closely related to household consumption from own-produced food than consumption of market-purchased food. However, more recent studies have obtained divergent results in comparison with those of the preceding mentioned studies. For example, Sibhatu et al. [53] found that improving small farmers' access to markets seems to be a more effective strategy in improving nutrition than promoting production diversity on subsistence farms. Similarly, Romeo et al. [48] conclude that agricultural production diversification is positively and significantly associated with household dietary diversity, but livestock ownership shows stronger significant level in comparison with production diversification, thereby implying that supporting investments in diversified livelihood system in general and livestock in particular are required to increase household dietary diversity. Djokoto et al. [12] concluded that vegetable diversification offers great potential for improving livelihood of cocoa-based farm households in Ghana. Therefore, it is important to understand the relationship between crop diversity and dietary diversity 
and identify appropriate determinants to dietary diversity using appropriate estimation methods.

Other than the above-mentioned studies, there has been limited research work to examine the causality between crop diversity and economic access to a variety of foods (i.e., household dietary diversity) at household level in sub-Saharan Africa. As a contribution to the global discourse on the interlinks between household dietary diversity and nutrition and the growing body of literature on the agriculture-nutrition-health linkages nexus, it is important to know how smallholders respond to different transitional changes. Of particular importance is the need to capture detailed household-level survey data related to the associated changes in crop production and consumption patterns that is specific to identified locales. Most important, from a nutritional standpoint, would be the need to ascertain whether smallholders have better economic access to a variety of foods from increased crop diversity through the inclusion of micronutrientrich vegetables into dominant staple-based cropping systems. The objective of this study therefore is to measure the effect of crop diversification on household dietary diversity in the study area while accounting for the interaction terms in crop income and crop diversification.

\section{Data and methods}

\section{Survey design and data sources}

Extension officers from agricultural departments in the respective study districts and opinion leaders from the respective villages collaborated to generate a population list of farmers who cultivate maize and vegetables. From the generated list, a stratified random sample was selected for the purpose of the study. Sampled respondents were classified into two farm household categories, viz "maize-producing households" and "maize-cum-vegetable-producing households." Farmers designated as "maize-producing households" were those that cultivated maize and other staple crops with no vegetables, whereas "maize-cum-vegetable-producing households" cultivated maize and other staples and vegetables. To correct for sampling bias among these two groups, an equal number was randomly selected from each group15 farm households each were selected from each category, making a total of 30 farm households per village. Overall, 300 farm households selected from 10 villages in the Babati, Kongwa and Kiteto districts of Tanzania (Table 1) were surveyed from July to August 2013 using a structured questionnaire.

The survey was conducted in three stages: pre-pilot, pilot and main survey. In the pre-pilot survey, districts and villages were selected based on predetermined sites based on the Africa Research in Sustainable Intensification for the Next Generation (Africa RISING) Eastern
Table 1 Number of sampled respondents by region and district. Source: Field Survey 2013

\begin{tabular}{lrrrr}
\hline Region/district & Babati & Kiteto & Kongwa & Total \\
\hline Regions & & & & \\
Manyara & 120 & 90 & 0 & 210 \\
Dodoma & 0 & 0 & 90 & 90 \\
Overall & 120 & 90 & 90 & 300 \\
\hline
\end{tabular}

and Southern Africa Phase I project sites. Based on key informative interviews with extension officers in the study region, it was confirmed that the selected districts majorly produce tomato, African eggplant (S. aethiopicum L.), cv. DB3, and amaranth (Amaranthus spinosus L.), cv. Madiira 1 , along with other major staple crops such as maize and paddy rice. The distance from home to nearest access to market varies between 1.1 and $27 \mathrm{~km}$ with an average of about $4.8 \mathrm{~km}$. The buyers from these markets also differ in terms of type of produce purchased. For farmers who produce maize and other staple crops, the average distance to the market is $9.0 \mathrm{~km}$, whereas for farmers who produce vegetables and staple crops including maize, the average distance to market is $3.4 \mathrm{~km}$. The project sites were selected based on pre-demarcated and developmental domains for sustainable intensification (i.e., agroecological potential, population density and market access) with diverse agro-climatic systems suitable for integrated maize-based farming systems, population and livestock density trajectories. Given the special requirements of vegetable production and that the critical role irrigation plays in vegetable cultivation, however, some villages selected for the main survey and subsequent implementation of project activities were not originally part of the target Africa RISING Phase I project sites. These villages were included for vegetable-related work packages based on their high irrigation potential as well as the possibility of achieving more impact through the integration of vegetables into maize-based farming systems. During the pilot survey, a structured questionnaire was prepared and pretested in the field, and modifications were made based on enumerator observations and feedback comments received from respondents. The main survey involved a one-on-one interaction with respondents using the pretested and finalized structured questionnaire.

\section{Methodological framework Measurement of dietary diversity}

Dietary diversity is a qualitative measure of food consumption that reflects household access to a variety of foods (food groups) [37, 49]. In general, there are two ways of measuring dietary diversity: the dietary diversity score (DDS) and the food variety score (FVS). DDS 
is based on a food group count while FVS is based on single food count. These two measures are widely used in the context of developing countries due to the simplicity of the measurement approaches. However, Ruel [49] shows that DDS is a stronger determinant of nutrient adequacy than FVS. Therefore, increasing the number of food groups has a greater impact on dietary quality than increasing the number of individual foods in the diet. It has the added merit of being simpler and easier to use under field survey conditions.

In this paper, as recommended by Ruel [49], the DDS was employed as a method to measure dietary diversity. The DDS described by FAO [18] guidelines consists of a simple count of food groups that a household or an individual has consumed over the preceding 24-h recall period (see "Appendix 1" Table 5). However, no international consensus exists on which food groups to include in the scores [18]. Therefore, 16 food groups ("Appendix 1" Table 5) were constructed based on local food consumption patterns [66] obtained from key informant interviews since dietary patterns vary substantially between cultures, as recommended by Ruel [49], food groupings were defined locally. Inference is drawn from the two types of DDS measurement approaches earlier enumerated: the Individual Dietary Diversity Score (IDDS) and the Household Dietary Diversity Score (HDDS). The IDDS aims to reflect the nutrient adequacy, whereas the HDDS represents a snapshot of the economic ability of a household to access a variety of foods [18]. We chose to use HDDS in our estimation. The reason for choosing HDDS rather than IDDS is because within the context of the study locale, "maize-cum-vegetable-producing households" tend to have a relatively higher crop diversification which in turn improves their economic accessibility to varieties of food groups as compared to "maize-producing households". In order to practically estimate HDDS, the FAO [18] guidelines recommend that where there are too many observed food groups, some food groups must be aggregated such that with the overall potential total grouping should vary between 0 and 12 . Therefore, based on the raw data obtained from the field study in "Appendix 1," food groups 3, 4 and 5 were aggregated into a single group designated as "vegetables." Food groups 6 and 7 were likewise aggregated into a single group designated as "fruits." Food groups 8 and 9 are integrated into a single "meat" group category. The rest of the food groups were retained for the estimation. Thus, a total of 12 food groups were used for HDDS measurement with the aggregate food groups listed in Table 3.

\section{Measurement of crop diversity}

Crop diversity was measured in the reference agricultural season through Simpson's Index (SI) [54]. The Simpson's
Index describes evenness of the distributed area under cultivation of different crop species in a cropping pattern.

$$
\mathrm{SI}=1-\sum_{i=1}^{n} P_{i}^{2},
$$

where $P_{i}$ is proportionate area (or value) of $i$ th crop. Based on these variable measurements, a few authors have identified factors that influence crop diversity in many developing countries [4, 9, 11, 28, 44], and also in Southern Africa as exemplified by Shaxson and Tauer [52], who measured determinants of crop diversity in Malawi. Further, Joshi et al. [29] examined the impact of crop diversification (Simpson's Index) on income of smallholders who largely grow vegetables in India. The authors found positive relationship between crop diversification and income of smallholders. In this study, the Simpson's Index was estimated based on farmers who cultivated different crop species by the households over the 2013 rainy season (December 2012 to June 2013). As the data collection took place from July to August 2013, it was much easier for farmers to recall their cultivated crop input-output data details during the preceding rainy season prior to the field survey.

\section{Econometric framework}

This paper examined the effect of crop diversity on dietary diversity of farm households in the study regions, by estimating a linear multiple regression model using cross-sectional data collected from the primary survey. The reason for using a multiple linear regression model is to control other covariates [i.e., individual and household characteristics, land ownership, regional effects, expenditure on food and non-food items (i.e., proxy for household wealth and well-being)], access to credit and revenue from crop sales (i.e., crop income) while estimating the net effect of crop diversity on household dietary diversity and also the interaction effect between crop income and crop diversity on household dietary diversity.

The explanatory variables for the underlying model are: Simpson's Index (SI), household head characteristics: gender, level of education and age, and household characteristics (including monthly expenditure on food and non-food items, and size of households in terms of number of people living in a household). In addition to these variables, we also explore other independent variables in the model, agricultural characteristics include owned cropped area, share of irrigated area, proportion of total vegetables consumed from own production, access to markets (i.e., distance to market from farm), sales transaction time at sales location, total hours to reach market from farm, access to ICT tools (i.e., radio and mobile), 
access to input services (i.e., credit and extension services) and district dummies. Monthly expenditure is a proxy measure for household wealth; it indicates whether a farmer has the potential to cultivate more crops for sale in the market to earn more income, which can then be used to purchase more diversified foods as majorly farmers source their income from agricultural activities. Hence, we hypothesize a positive relationship between monthly food expenditure and the household dietary diversity score. We use a dummy for female headed household where female is 1 and male is 0 . Gross crop area represents operated household-level landholding size in hectares. Based on the fit of model, the unobserved characteristics are identified as log of total monthly food expenditure, share of irrigated area, dummy for access to credits, extension services in last 12 months and access to mobile for agricultural activities and radio. In addition to the above explanatory variables, the model also incorporated quadratic function and interaction effect for the variables Simpson's Index (SI) and crop income, the reason behind first, there is no linear relationship between household dietary diversity and crop diversification and also with crop income (Fig. 1) which indicates that linear relationship is not expected between household dietary diversity, crop income and crop diversification. However, crop income will have increasing effect on household dietary diversity at decreasing rate at some point of time which indicate, larger share of income for the poorer households is allocated to food purchase. Second, the propensity of expenditure on food decrease as the crop income goes up. Therefore, quadratic relationship is observed between the crop income and household dietary diversity; hence, it is necessary to identify the optimal level of crop income and crop diversification where increasing and crop diversification has positive impact on household dietary diversity.

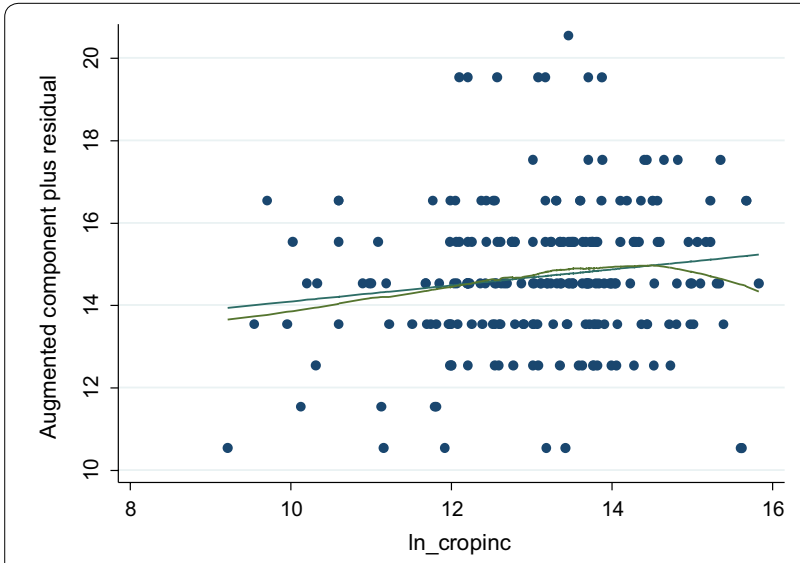

Fig. 1 Augmented component-plus-residual plot for revenue from crop sales by farm households

\section{Results}

Household dietary diversity score shows that on average, households consumed 6 types of food groups over the preceding 24-h recall period at the time of the survey (Table 2). The most consumed food groups are cereals $(99 \%)$, vegetables $(90 \%)$, oils and fats $(88 \%)$, and spices (79\%). However, the most nutrition food groups such as eggs, fruits and fish and other food groups were consumed by less than $15 \%$ of the respondents. White tubers and roots, fish and sea foods, eggs and fruits are considered to be the least consumed food groups (Table 3). Among the regions, Manyara had a higher dietary diversity compared to the overall mean of the two study regions, while Dodoma region had the lowest score. Household dietary diversity results for the Manyara region were significantly different from those of the Dodoma region, whereas the Simpson's Index estimates did not vary significantly across the 2 regions. Simpson's Index, however, was found not to differ significantly between the two farm household categories (i.e., maizeproducing households and maize-cum-vegetable-producing households).

We used a multiple linear regression model to control the effect of other covariates on dietary diversity to capture the net effect of crop diversity (Table 4). To this end, two different models (I \& II) on the effect of crop diversity on dietary diversity were estimated. In Model 1 , augmented component-plus-residual plot identifies the presence of nonlinearity as crop income exhibited a quadratic relation with dietary diversity (Fig. 1), and hence, squared version of crop income variable was added in Model 1. Similarly, Simpson's Index also

Table 2 Summary indicator descriptive statistics and significance level of dietary diversity, crop count and Simpson's Index by various covariates. Source: Field Survey 2013

\begin{tabular}{llll}
\hline Indicators & $\begin{array}{l}\text { Samples } \\
\text { (N) }\end{array}$ & $\begin{array}{l}\text { Household } \\
\text { dietary diversity }\end{array}$ & $\begin{array}{l}\text { Crop diversity } \\
\text { Simpson's Index }\end{array}$ \\
\hline $\begin{array}{l}\text { Overall } \\
\text { By region }\end{array}$ & 300 & $6.1(1.7)$ & $0.5(0.2)$ \\
$\quad \begin{array}{l}\text { Manyara } \\
\text { Dodoma (Base) }\end{array}$ & 207 & $6.3(1.7)^{*}$ & $0.5(0.2)$ \\
$\begin{array}{l}\text { By farm households } \\
\text { Category }\end{array}$ & 88 & $5.6(1.6)$ & $0.5(0.2)$ \\
$\begin{array}{l}\text { Maize-producing } \\
\text { households } \\
\text { (base) }\end{array}$ & 150 & $6.0(1.8)$ & $0.5(0.2)$ \\
$\begin{array}{l}\text { Maize-cum-vege- } \\
\text { table producing } \\
\text { households }\end{array}$ & 150 & $6.1(1.6)$ & $0.5(0.2)$ \\
$\begin{array}{l}\text { * } p<0.01 ; * * \\
\text { brackets }\end{array}$ & & \\
\end{tabular}


Table 3 Aggregation of food groups access by farm households

\begin{tabular}{ll}
\hline Food groups $^{\mathbf{b}}$ & Percent $^{\mathbf{a}}$ \\
\hline Cereals & 99 \\
Vegetables & 90 \\
Oils and fats & 88 \\
Spices, condiments and beverages & 85 \\
Sweets & 79 \\
Legumes, nuts and seeds & 54 \\
Meat & 28 \\
Milk and milk products & 28 \\
White tubers and roots & 19 \\
Fruits & 14 \\
Fish and other seafood & 14 \\
Eggs & 11 \\
\hline
\end{tabular}

a Percent of food groups may not add up 100 percent as farm households may have access to multiple food groups

${ }^{b}$ Detailed items that includes in each food groups provided in Appendix 1 Table 5

has a nonlinear relationship with dietary diversity and identifies the presence of a polynomial distribution pattern (Fig. 2) and hence the interaction effect between crop income and Simpson's Index in Model 2 as farmers tend to diversify if they feel those crops might generate revenue. This might have consequent influences on dietary diversity at certain point. Since the variance inflation factor (VIF) score for all explanatory variables is more than 10 and there was no multicollinearity issues except for the squared term of crop income and Simpson's Index ("Appendices 3 and 4" Tables 7, 8), squaring these variables may not be an empirical issue when we interpret results for these variables [60]. In both models, when crop income increases, the household dietary diversity score also increases, but in Model 1, the square of crop income variable shows a negative relationship, which indicates crop income increases dietary diversity at a decreasing rate, until it reaches US $\$ 280$, after which the HDDS will decrease. Ultimately, this tends to validate the presence of a quadratic relationship with HDDS (Fig. 3). Similarly, the interaction effect between Simpson's Index and crop income (Model 2) shows that both variables were significantly associated with dietary diversity after controlling for other covariates. When we introduce the interaction effect between Simpson's Index and crop income in the model, the coefficient of Simpson's Index and crop income cannot be interpreted directly with the presence of the interaction effect in the regression model. Therefore, the coefficient of Simpson's Index (i.e., 10.16) and crop income (0.387) are main effects on HDDS which includes interaction effects (i.e., -0.868 ) when we interpret main effects on HDDS.
Table 4 Multiple linear regression functions: the effect of crop diversity on dietary diversity

\begin{tabular}{|c|c|c|}
\hline Variables & $\begin{array}{l}\text { Model } 1 \\
\text { Quadratic effect }\end{array}$ & $\begin{array}{l}\text { Model } 2 \\
\text { Interaction effect }\end{array}$ \\
\hline \multicolumn{3}{|l|}{$\begin{array}{l}\text { Dependent variable: dietary } \\
\text { diversity }\end{array}$} \\
\hline $\begin{array}{l}\text { Head of the household-female } \\
\qquad(1=\text { yes, } 0=\text { no })\end{array}$ & $\begin{array}{l}0.0247 \\
(0.0900)\end{array}$ & $\begin{array}{l}0.0234 \\
(0.0862)\end{array}$ \\
\hline Age (years) & $\begin{array}{l}-0.00109 \\
(-0.0770)\end{array}$ & $\begin{array}{l}-0.00186 \\
(-0.133)\end{array}$ \\
\hline $\begin{array}{l}\text { Level of education for the } \\
\text { respondent (primary level_- } \\
\text { dummy) }\end{array}$ & $\begin{array}{l}2.099^{* *} \\
(2.509)\end{array}$ & $\begin{array}{l}2.086^{* *} \\
(2.568)\end{array}$ \\
\hline Secondary level_dummy & $\begin{array}{l}1.181^{*} \\
(1.717)\end{array}$ & $\begin{array}{l}1.142^{*} \\
(1.740)\end{array}$ \\
\hline $\begin{array}{l}\text { Higher secondary and above- } \\
\text { dummy }\end{array}$ & $\begin{array}{l}0.983 \\
(1.292)\end{array}$ & $\begin{array}{l}1.056 \\
(1.456)\end{array}$ \\
\hline $\begin{array}{l}\text { Household size (number of fam- } \\
\text { ily members) }\end{array}$ & $\begin{array}{l}-0.00954 \\
(-0.144)\end{array}$ & $\begin{array}{l}-0.0116 \\
(-0.182)\end{array}$ \\
\hline $\begin{array}{l}\text { Number of times met with } \\
\text { public extension officers in last } \\
4 \text { months }\end{array}$ & $\begin{array}{l}0.206^{* *} \\
(2.472)\end{array}$ & $\begin{array}{l}0.213^{* *} \\
(2.585)\end{array}$ \\
\hline Ownership of radio & $\begin{array}{l}0.324 \\
(1.168)\end{array}$ & $\begin{array}{l}0.246 \\
(0.882)\end{array}$ \\
\hline Ownership of mobile & $\begin{array}{l}-0.0554 \\
(-0.176)\end{array}$ & $\begin{array}{l}0.0164 \\
(0.0529)\end{array}$ \\
\hline Own farm area (acre) & $\begin{array}{l}0.0167 \\
(1.628)\end{array}$ & $\begin{array}{l}0.0123 \\
(1.424)\end{array}$ \\
\hline Ln monthly food expenditure & $\begin{array}{l}0.358^{* *} \\
(2.362)\end{array}$ & $\begin{array}{l}0.426^{* * *} \\
(2.695)\end{array}$ \\
\hline $\begin{array}{l}\text { Ln monthly non-food expendi- } \\
\text { ture }\end{array}$ & $\begin{array}{l}0.0154 \\
(0.103)\end{array}$ & $\begin{array}{l}-0.0108 \\
(-0.0722)\end{array}$ \\
\hline $\begin{array}{l}\text { Ln revenue generated from crop } \\
\text { sales per transaction (crop } \\
\text { income) }\end{array}$ & $\begin{array}{l}3.107^{*} \\
(1.792)\end{array}$ & $\begin{array}{l}0.387^{*} \\
(1.655)\end{array}$ \\
\hline Simpson's Index & $\begin{array}{l}-1.207^{*} \\
(-1.957)\end{array}$ & $\begin{array}{l}10.16^{*} \\
(1.664)\end{array}$ \\
\hline $\begin{array}{l}\text { Interaction effect between SI * } \\
\text { crop income }\end{array}$ & & $\begin{array}{l}-0.868^{*} \\
(-1.845)\end{array}$ \\
\hline $\begin{array}{l}\text { Access to credit (dummy } \\
1=\text { yes, } 0=\text { no) }\end{array}$ & $\begin{array}{l}0.565 \\
(1.583)\end{array}$ & $\begin{array}{l}0.722^{* *} \\
(2.058)\end{array}$ \\
\hline Kiteto & $\begin{array}{l}-0.139 \\
(-0.418)\end{array}$ & $\begin{array}{l}-0.141 \\
(-0.415)\end{array}$ \\
\hline Kongwa & $\begin{array}{l}-0.163 \\
(-0.493)\end{array}$ & $\begin{array}{l}-0.170 \\
(-0.504)\end{array}$ \\
\hline $\begin{array}{l}\text { Square of } L n \text { revenue generated } \\
\text { from crop sales per transaction } \\
\text { (crop income) }\end{array}$ & $\begin{array}{l}-0.121^{*} \\
(-1.783)\end{array}$ & \\
\hline Constant & $\begin{array}{l}-18.81 \\
(-1.623)\end{array}$ & $\begin{array}{l}-4.522 \\
(-1.084)\end{array}$ \\
\hline Observations & 200 & 200 \\
\hline R-squared & 0.180 & 0.181 \\
\hline
\end{tabular}

Robust $t$-statistics in parentheses

*** $p<0.01$; ** $p<0.05 ;{ }^{*} p<0.1$ 


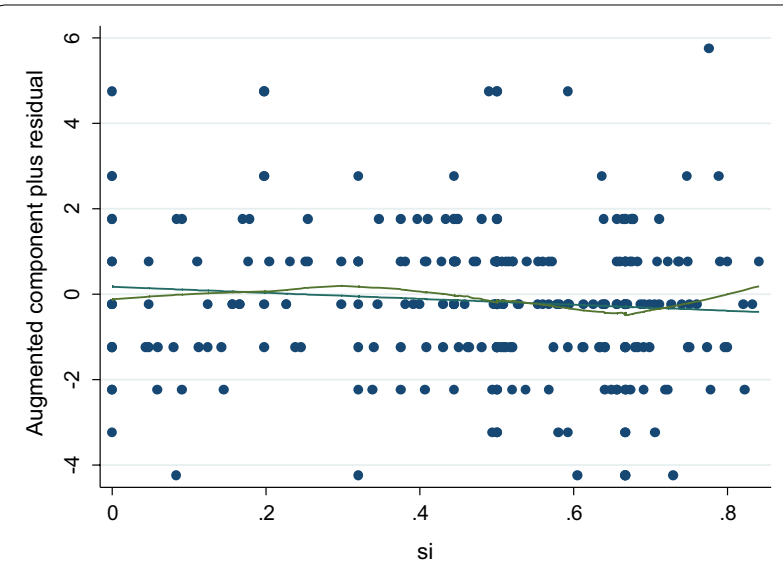

Fig. 2 Augmented component-plus-residual plot for Simpson's Index

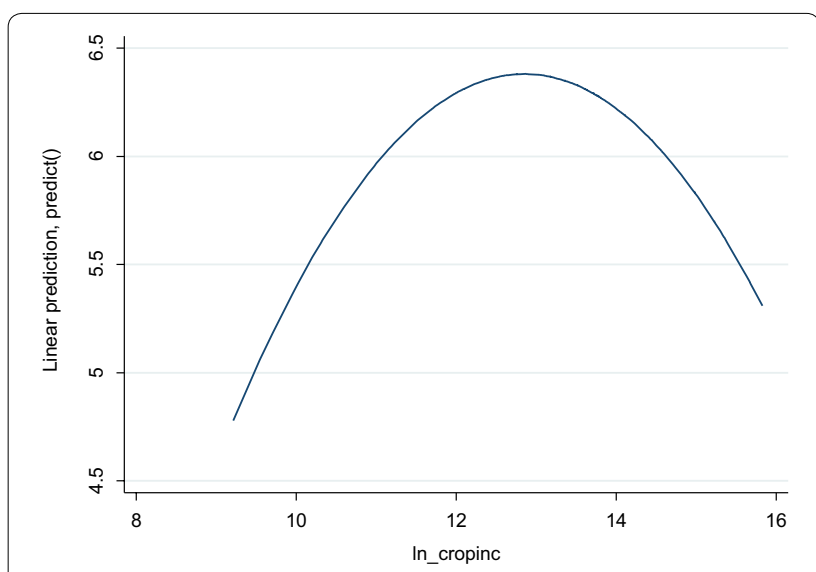

Fig.3 Quadratic function-crop income

The coefficient of Simpson's Index shows an average crop income of US\$318 (TZS 503,832), ${ }^{1}$ a one-unit increase in Simpson's Index, associated with -1.318 unit increase in dietary diversity. This implies that HDDS increases with decreasing rate of Simpson's Index. However, this decreased rate of Simpson's Index starts increasing when threshold or breakeven point for crop income is US\$85 (TZS 134,500) per transaction, which implies below this crop income level, characterized largely by poorer households tends to increase their HDDS when they diversify their crop production. This in turn leads to an improved revenue from crop sales (calculation in "Appendix 5" and Fig. 4).

Similarly, the coefficient of crop income shows that an average Simpson's Index value of 0.47 , a one-unit increase in crop income per sales transaction, results in a 0.021 reduction in dietary diversity, which implies that

\footnotetext{
${ }^{1}$ Exchange rate is 1582.16 TZS per US\$ as on August, 1, 2013.
}

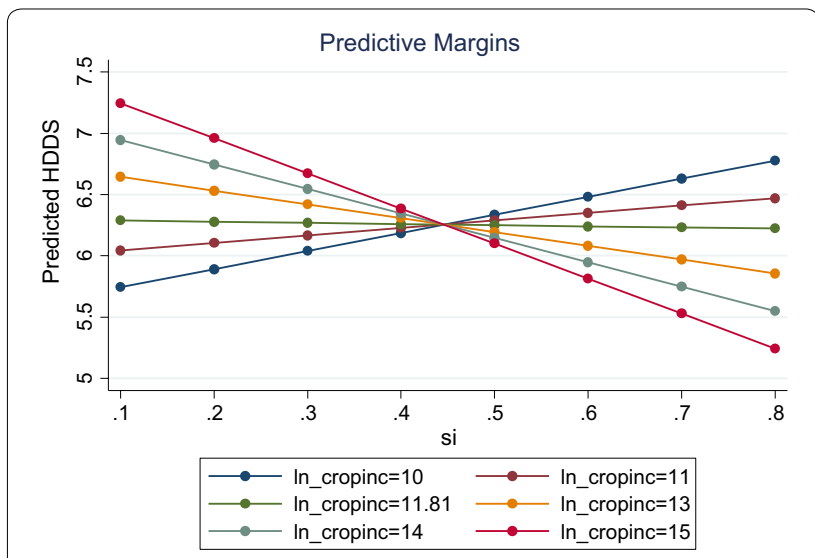

Fig. 4 Interaction effect: slope coefficient for Simpsons'Index

HDDS increases with a decreasing rate of crop income. However, the threshold point for Simpson's Index is 0.45 , which implies below this threshold point, farmers tend to increase their HDDS when crop income increases by diversifying their crop until they reach their optimal Simpson's Index level of 0.45 (calculation in "Appendix 6" and Fig. 5).

In sum, both regression models indicate that there is no linear relationship between crop diversity and dietary diversity. Particularly poorer and smallholders are more exposed from the effect of crop diversification and crop income toward increasing in their household dietary diversity score. By looking at each explanatory variable in both models, the dietary diversity score was higher farmers who attained primary and secondary level education. Clearly, farmers who have attained a primary and secondary level educational might have better knowledge about nutrition and dietary intake patterns, and hence, their dietary diversity score was significantly different and higher than for farmers who have no formal

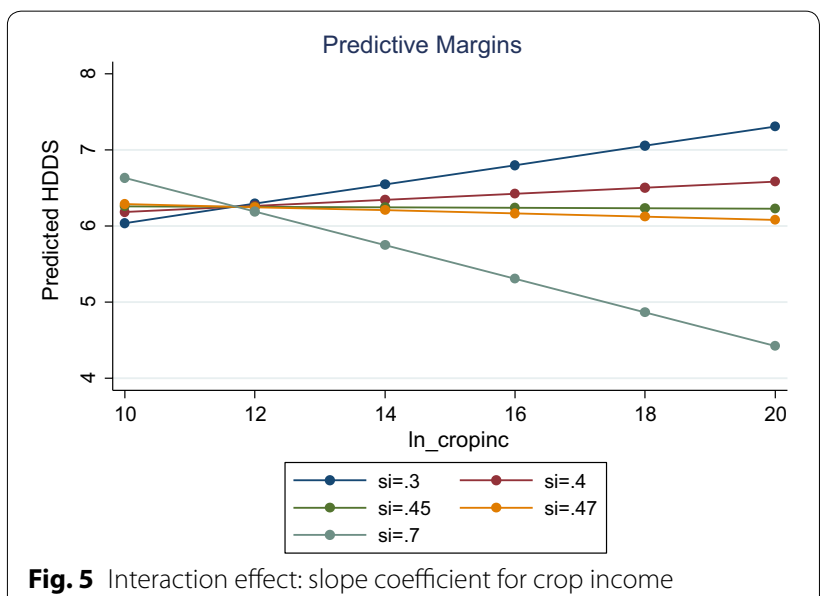


education. In addition, the dietary diversity score was higher for farmers who frequently meet with agricultural extension agents in the last 4 months; which indicates that there is possibility that agricultural extension agents might exchange information on agriculture and nutritional information through several development project interventions. The ownership of radio shows positive coefficient, but it does not have a significant relationship with dietary diversity score. Further, the results show that dietary diversity score increases if farm household increases their monthly expenditure on food. If farmers have access to credit, then farmers tend to increase their household dietary diversity. Finally, the district dummies (Kiteto and Kongwa) did not show any significant impact on household dietary diversity as compared to base category (i.e., Babati district), which means there was no significant differences in dietary diversity due to district effects.

\section{Discussion}

Due to the presence of interaction effect between Simpson's Index and crop income, simply increasing Simpson's Index does not influence dietary diversity of farm households. It is much more critical and significant to increase the revenue generated from those diversified crops along with other socioeconomic endowment and household behavioral characteristics. This is applicable to smallholders who received crop incomes less than US $\$ 85$ per sales transaction and per season. It is clear that the level of education has a strong influence on dietary diversity. It indicates that dietary diversity of households can be increased by improving the farmers' level of education. Monthly per capita expenditure on food is positively associated with dietary diversity. If households have greater expenditure on food, it leads to higher dietary diversity as well. This result indicates that apart from nutrition security, dietary diversity can also be linked to some key food security indicators by linking monthly per capita expenditure of both food and non-food items as suggested by Hoddinott and Yohannes [23]. Land ownership has a positive relationship with dietary diversity and insignificant results. In order to produce more robust results, the model estimated results based on variancecovariance matrix of the estimators.

Despite the observed findings of this study, it is worth mentioning a couple of limitations such as seasonal effect on dietary diversity and limited sample size. For future research, the use of panel datasets, which was not the case in the present study, might be very helpful in obtaining higher observations and variation in datasets to obtain more robust model estimates. Panel datasets would have the added advantage of capturing smallholder behavioral responses over time in comparison with single observations from a typical cross-sectional survey used for this study. The results also underscore a large scope to explore gender disaggregated roles in crop diversity of smallholder vis-à-vis dietary diversity in future research. Also, since aim of this study was to measure the impact of crop diversity on economic access to variety of foods at the household level (i.e., household dietary diversity), the Individual Dietary Diversity Score was not considered in this study. However, the contribution of vegetables to nutrient adequacy (i.e., individual dietary diversity) is an important research as well as development question that should be considered for future research studies. The limitations notwithstanding do not undermine the findings of the present study but should be considered as gaps for further literature contributions to the ongoing discourse and growing body of literature.

\section{Conclusion}

This paper explored whether an increased diversity of crops in farmers' fields leads to increased economic access to diversified food groups. Increasing crop diversity (Simpson's Index), a metric accounting for both species richness and evenness and crop income, was found to positively influence household dietary diversity in the study region. However, this cannot be interpreted directly as these two variables have an interaction effect on the dietary diversity score. This empirically implies that under average crop income scenarios, households that diversify their crop production will tend to increase their dietary diversity from their existing dietary diversity score at a decreasing rate. However, under below average crop income threshold scenarios, farmers tend to increase their dietary diversity score from their existing score at an increasing rate when they diversify into crops with relative high farm gate values and accrue higher net revenues in the market. In other words, particularly smallholders who receive crop income less than the average crop income threshold generated from per sales transaction (i.e., threshold level is US $\$ 85$ per sales transaction and season) and grow crops that attract better market value to improve their dietary diversity at the household level. This will in turn enhance their economic access to a variety of foods for household consumption. Farm households can also access diverse vegetable species, while ensuring adequate and consistent supplies at the desired time over a reference growing season. Though gender had a relatively lower effect on dietary diversity, compared to other socioeconomic variables, there is more scope for female decision makers and controllers of household income to positively influence dietary diversity at household level. Monthly expenditure on food also positively influenced household 
dietary diversity, indicating that farm households that spend more of their income on market-purchased food have consistent increases in the pattern of their dietary diversity at the household level. The results suggest that improving economic access to a variety of foods at smallholder household level by diversifying diets through increased crop diversification should be encouraged within maize-based farming systems of the study locale, through integration of micronutrient-rich foods.

Overall, to increase household dietary diversity, an enabling policy environment that will encourage farmers particularly smallholders to diversify into crops with high farm gate values and accrue higher incomes along with other socioeconomic endowment and behavioral characteristics of households such as education, monthly per capita food expenditure, access to credit and frequency of interaction with extension officers will have a strong influence on dietary diversity scores. These variables positively and significantly influenced household dietary diversity at less than $5 \%$ probability level. In addition, community sensitization campaigns and nutritional education on the nutritional benefits of diversified diets through agricultural extension agents and public sector nutrition and health officers need to be increased in the study locale and other agro-climatic zones with similar settings, particularly among women farmers, most of who play a critical role in making production and consumption decisions within most households.

\section{Abbreviations \\ HDDI: Household Dietary Diversity Index; SI: Simpson's Index; VIF: variance inflation factor; FVS: food variety score; DDS: dietary diversity score; IDDS: Individual Dietary Diversity Score (IDDS); Africa RISING: Africa Research in Sustainable Intensification for the Next Generation.}

\section{Authors' contributions}

SR was involved in sampling design, development of farm household survey questionnaire, econometric framework, data analysis and drafting the paper. VA-S was involved in the study design, development of field survey instruments and reviewed and proofread the entire manuscript. MB was involved in the review and beefing of the paper. TB and AS helped in improvement of econometric framework and data analysis. ID and PJL helped in data collection and data compiling. All authors read and approved the final manuscript.

\section{Author details}

${ }^{1}$ International Potato Center (CIP), Sub-Saharan Africa (SSA) Regional Office, ILRI Campus, Nairobi, Kenya. ${ }^{2}$ World Vegetable Center, West and Central Africa - Coastal and Humid Region, Cotonou, Benin. ${ }^{3}$ Business Development Economist, Natural Resources Institute, University of Greenwich, Central Avenue, Kent ME44TB, UK. ${ }^{4}$ International Potato Center (CIP), Nampula, Mozambique. ${ }^{5}$ International Institute of Tropical Agriculture (IITA), PO Box 10, Duluti, Arusha, Tanzania. ${ }^{6}$ World Vegetable Center, Eastern and Southern Africa, PO Box 10, Duluti, Arusha, Tanzania.

\section{Acknowledgements}

The authors wish to express their appreciation to Dr. Jackie Hughes for her valuable comments and suggestions on the initial draft of this paper. We are also grateful to Maureen Mecozzi for her excellent editing of the paper. We also thank the district authorities in the study area, all enumerators who were involved in data collection, analysis and report compilation and the farmers who participated in the study for their time and support. We are grateful to the 3 anonymous referees for their constructive criticisms that helped in improving the quality of this paper.

\section{Competing interests}

The authors declare that they have no competing interests.

Availability of data materials

Data are available on request.

\section{Ethical approval and consent to participate}

Appropriate ethical clearance was sort verbally from respective communities and local government authorities. All respondents who participated in the field study were duly informed about the purpose of the study and their right to decline participation in the study, and verbal consent was obtained from all participants prior to interviews.

\section{Funding}

The authors wish to acknowledge the financial support from the Africa Research in Sustainable Intensification for the Next Generation (Africa RISING) East and Southern Africa Project, supported by the United States Agency for International Development (USAID) as part of the US Government's Feed the Future initiative to control global hunger and malnutrition.

\section{Publisher's Note}

Springer Nature remains neutral with regard to jurisdictional claims in published maps and institutional affiliations.

\section{Appendix 1}

See Table 5. 
Table 5 Food groups used to measure dietary diversity. Source: Field survey 2013

\begin{tabular}{|c|c|c|}
\hline No. & Food group & Examples \\
\hline 1 & Cereals & $\begin{array}{l}\text { Corn/maize, rice, wheat, sorghum, millet or any other grains or food made from these (e.g., } \\
\text { bread, noodles, porridge or other grain products) and local foods (e.g., ugali, porridge or paste) }\end{array}$ \\
\hline 2 & White roots and tubers & Irish potato, cocoyam, cassava or other foods made from roots \\
\hline 3 & Vitamin A-rich vegetables and tubers & $\begin{array}{l}\text { Pumpkin, carrot, squash or sweet potato that are orange inside and other locally available vita- } \\
\text { min A-rich vegetables (e.g., red sweet pepper) }\end{array}$ \\
\hline 4 & Dark green leafy vegetables & $\begin{array}{l}\text { Dark green leafy vegetables, including wild forms and locally available vitamin A-rich leaves such } \\
\text { as amaranth, cassava leaves, kale, spinach }\end{array}$ \\
\hline 5 & Other vegetables & Other vegetables (e.g., tomato, onion, eggplant) and other locally available vegetables \\
\hline 6 & Vitamin A-rich fruits & $\begin{array}{l}\text { Ripe mango, cantaloupe, apricot (fresh or dried), ripe papaya, dried peach and 100\% fruit juice } \\
\text { made from these and other locally available vitamin A-rich fruits }\end{array}$ \\
\hline 7 & Other fruits & Other fruits, including wild fruits and 100\% fruit juice made from these \\
\hline 8 & Organ meat & Liver, kidney, heart or other organ meats or blood-based foods \\
\hline 9 & Flesh meats & Beef, pork, lamb, goat, rabbit, game, chicken, duck, other birds, insects \\
\hline 10 & Eggs & Eggs from chicken, duck, guinea fowl or any other egg \\
\hline 11 & Fish \& seafood & Fresh or dried fish or shellfish \\
\hline 12 & Legumes, nuts \& seeds & $\begin{array}{l}\text { Dried beans, dried peas, lentils, nuts, seeds or foods made from these (e.g., hummus, peanut } \\
\text { butter) }\end{array}$ \\
\hline 13 & Milk \& milk product & Milk, cheese, yogurt or other milk products \\
\hline 14 & Oils \& fats & Oil, fats or butter added to food or used for cooking \\
\hline 15 & Sweets & $\begin{array}{l}\text { Sugar, honey, sweetened soda or sweetened juice drinks, sugary foods such as chocolates, } \\
\text { candies, cookies and cakes }\end{array}$ \\
\hline 16 & Spices, condiments, beverages & $\begin{array}{l}\text { Spices (black pepper, salt), condiments (soy sauce, hot chili sauce), coffee, tea, alcoholic bever- } \\
\text { ages }\end{array}$ \\
\hline
\end{tabular}

\section{Appendix 2}

See Table 6.

Table 6 Summary statistics of variables used in multiple regression function

\begin{tabular}{|c|c|c|c|c|c|}
\hline Variable & Obs & Mean & Std. & Min & Max \\
\hline Dietary diversity & 278 & 6.08 & 1.72 & 2 & 12 \\
\hline Head of the household—female ( $1=$ yes, $0=$ no) & 278 & 0.31 & 0.46 & 0 & 1 \\
\hline Age (years) & 278 & 42.37 & 10.65 & 18 & 77 \\
\hline Level of education for the respondent (primary level—dummy) & 278 & 0.08 & 0.27 & 0 & 1 \\
\hline Secondary level—dummy & 278 & 0.82 & 0.38 & 0 & 1 \\
\hline Higher secondary and above_-dummy & 278 & 0.06 & 0.24 & 0 & 1 \\
\hline Household size (number of family members) & 278 & 6.21 & 2.58 & 1 & 15 \\
\hline Number of times met with public extension officers in last 4 months & 277 & 0.48 & 1.21 & 0 & 10 \\
\hline Ownership of radio & 275 & 0.75 & 0.44 & 0 & 1 \\
\hline Ownership of mobile & 268 & 0.81 & 0.39 & 0 & 1 \\
\hline Own farm area (acre) & 278 & 9.39 & 18.03 & 0 & 159 \\
\hline Ln monthly food expenditure & 278 & 11.31 & 0.81 & 7 & 13 \\
\hline Ln monthly non-food expenditure & 257 & 9.89 & 1.10 & 7 & 12 \\
\hline Ln revenue generated from crop sales per transaction & 224 & 13.13 & 1.29 & 9 & 16 \\
\hline Simpson's Index & 278 & 0.47 & 0.22 & 0 & 1 \\
\hline Access to credit (dummy $1=$ yes, $0=$ no) & 277 & 0.13 & 0.34 & 0 & 1 \\
\hline
\end{tabular}

Source: Authors' calculation 


\section{Appendix 3}

See Table 7.

Table 7 Variance inflation factor for the quadratic function in Model 1

\begin{tabular}{|c|c|c|}
\hline Variable & VIF & $1 / \mathrm{VIF}$ \\
\hline Head of the household—female $(1=$ yes, $0=$ no $)$ & 1.21 & 0.823871 \\
\hline Age (years) & 1.44 & 0.696669 \\
\hline Level of education for the respondent (primary level—dummy) & 4.07 & 0.245586 \\
\hline Secondary level—dummy & 5.85 & 0.170826 \\
\hline Higher secondary and above_-dummy & 3.22 & 0.310418 \\
\hline Household size (number of family members) & 1.37 & 0.729139 \\
\hline Number of times met with public extension officers in last 4 months & 1.09 & 0.917749 \\
\hline Ownership of radio & 1.16 & 0.859902 \\
\hline Ownership of mobile & 1.22 & 0.821471 \\
\hline Own farm area (acre) & 1.61 & 0.620033 \\
\hline Ln monthly food expenditure & 1.23 & 0.810505 \\
\hline Ln monthly non-food expenditure & 1.31 & 0.761025 \\
\hline Ln revenue generated from crop sales per transaction (crop income) & 246.92 & 0.00405 \\
\hline Square of $L n$ revenue generated from crop sales per transaction (crop income) & 247.89 & 0.004034 \\
\hline Simpson's Index & 1.17 & 0.854201 \\
\hline Access to credit (dummy $1=$ yes, $0=$ no) & 1.14 & 0.873905 \\
\hline \multicolumn{3}{|l|}{ District } \\
\hline 12 & 1.51 & 0.663642 \\
\hline 21 & 1.5 & 0.666088 \\
\hline Mean VIF & 29.16 & \\
\hline
\end{tabular}

Source: Authors' calculation

\section{Appendix 4}

See Table 8.

Table 8 Variance inflation factor for the interaction effect in Model 2

\begin{tabular}{|c|c|c|}
\hline Variable & VIF & $1 / \mathrm{VIF}$ \\
\hline Head of the household—female ( $1=$ yes, $0=$ no $)$ & 1.21 & 0.824132 \\
\hline Age (years) & 1.44 & 0.696619 \\
\hline Level of education for the respondent (primary Level—dummy) & 4.07 & 0.245813 \\
\hline Secondary level_dummy & 5.82 & 0.171755 \\
\hline Higher secondary and above_dummy & 3.23 & 0.30913 \\
\hline Household size (number of family members) & 1.37 & 0.729964 \\
\hline Number of times met with public extension officers in last 4 months & 1.1 & 0.91308 \\
\hline Ownership of radio & 1.16 & 0.86186 \\
\hline Ownership of mobile & 1.21 & 0.826549 \\
\hline Own farm area (acre) & 1.49 & 0.670029 \\
\hline Ln monthly food expenditure & 1.27 & 0.788258 \\
\hline Ln monthly non-food expenditure & 1.32 & 0.7583 \\
\hline Ln revenue generated from crop sales per transaction (crop income) & 4.74 & 0.211021 \\
\hline Simpson's Index & 83.43 & 0.011985 \\
\hline Interaction effect between $\mathrm{SI}$ * crop income & 91.6 & 0.010917 \\
\hline Access to credit (dummy $1=$ yes, $0=$ no) & 1.15 & 0.866392 \\
\hline \multicolumn{3}{|l|}{ District } \\
\hline 12 & 1.51 & 0.663729 \\
\hline 21 & 1.5 & 0.667864 \\
\hline Mean VIF & 11.59 & \\
\hline
\end{tabular}

Source: Authors' calculation 

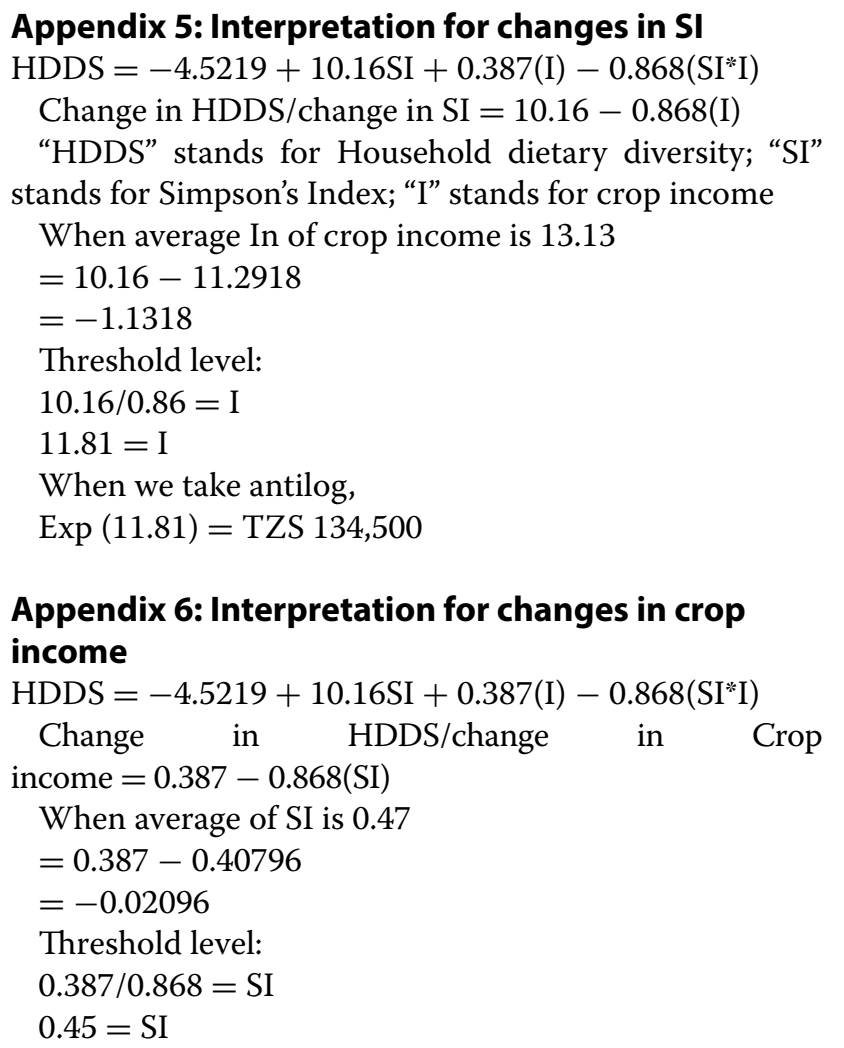

Received: 4 April 2017 Accepted: 16 June 2017

Published online: 21 October 2017

\section{References}

1. Abdulai A, Aubert D. A cross-section analysis of household demand for food and nutrients in Tanzania. Agric Econ. 2004;31(1):67-79.

2. Afari-Sefa V, Tenkouano A, Ojiewo C, Keatinge JDH, Hughes J. Vegetable breeding in Africa: constraints, complexity and contributions towards achieving food and nutritional security. Food Secur. 2012;4:115-27.

3. Alderman $\mathrm{H}$, Hoogeveen $\mathrm{H}$, Rossi M. Reducing child malnutrition in Tanzania: combined effects of income growth and program interventions. Econ Human Biol. 2006;4(1):1-23.

4. Ali J. Adoption of diversification for risk management in vegetable cultivation. Int J Veg Sci. 2015;21(1):9-20.

5. Ali M, Tsou SCS. Combating micronutrient deficiencies through vegetables - a neglected food frontier in Asia. Food Policy. 1997;22(1):17-38.

6. Arimond M, Ruel MT. Dietary diversity is associated with child nutritional status: evidence 11 demographic and health survey. J Nutr. 2004;134(10):2579-85.

7. Balasubramanian V, Sie M, Hijmans RJ, Otsuka K. Increasing rice production in sub-Saharan Africa: challenges and opportunities. Adv Agron. 2007;94:55-133.

8. Behrman JR. The economic rationale for investing in nutrition in developing countries. World Dev. 1993;21(11):1749-71.

9. Benin S, Smale M, Pender J, Gebremedhin B, Ehui S. The economic determinants of cereal crop diversity on farms in the Ethiopian highlands. Agric Econ. 2004;31(2-3):197-208.

10. Berti PR, Jones AD. Biodiversity's contribution to dietary diversity: Magnitude, meaning and measurement. In: Diversifying food and diets: Using agricultural biodiversity to improve nutrition and health. Taylor and Francis; 2013. pp. 186-206.
11. Birthal PS, Joshi PK, Devesh R, Amit T. Diversification in Indian agriculture toward high-value crops: the role of small farmers. Can J Agric Econ. 2012;61(1):61-91.

12. Djokoto JG, Afari-Sefa V, Addo-Quaye A. Vegetable diversification in cocoa-based farming systems Ghana. Agric Food Secur. 2017;6:6. doi:10.1186/s40066-016-0082-4

13. Drescher LS, Thiele S, Mensink GB. A new index to measure healthy food diversity better reflects a healthy diet than traditional measures. J Nutr. (2007);137(3):647-51.

14. Drewnowski A, Ahlstrom Renderson SA, Driscoll A, Rolls B. The dietary variety score: assessing diet quality in healthy young and older adults. J Am Diet Assoc. 1997;97:266-71.

15. Faber M, Craig S, Scott D. Dietary diversity in relation to other household food security indicators. Int J Food Saf Nutr Public Health. 2009;2(1):1-15.

16. FAO. The state of food insecurity in the world: Economic growth is necessary but not sufficient to accelerate reduction of hunger and malnutrition. Rome: Food and Agriculture Organisation of the United Nations (FAO); 2012.

17. FAO. The state of food and agriculture: food systems for better nutrition Rome: Food and Agriculture Organisation of the United Nations (FAO); 2013

18. FAO. Guidelines for measuring household and individual dietary diversity. Rome: Food and Agriculture Organization of the United Nations (FAO); 2011. http://www.fao.org/fileadmin/.../FAO-guidelines-dietary-diversity2011.pdf. Accessed 25 Aug 2013.

19. FAO. Proceedings for the international scientific symposium on food and nutrition security information: from valid measurement to effective decision making. Rome: Food and Agriculture Organisation of the United Nations (FAO); 2013b.

20. Hatløy A, Hallund J, Diarra MM, Oshaug A. Food variety, socioeconomicstatus and nutritional status in urban and rural areas in Koutiala (Mali). Public HealthNutr 2000; 3:57-65

21. Hatloy A, Torheim LE, Oshaug A. Food variety-a good indicator of nutritional adequacy of the diet? A case study from an urban area in Mali, West Africa. Eur J Clin Nutr. 1998;52(12):891-8.

22. Herforth A. Promotion of traditional African vegetables in Kenya and Tanzania: a case study of an intervention representing emerging imperatives in global nutrition. PhD thesis, Cornell University, Ithaca, NY; 2010.

23. Hoddinott J, Yohannes Y. Dietary diversity as a food security indicator. FCND brief 136. International Food Policy Research Institute (IFPRI), Washington D.C.; 2002

24. Hounsome N, Hounsome B, Tomos D, Edwards-Jones G. Plant metabolites and nutritional quality of vegetables. J Food Sci. 2008;73(4):48-65.

25. Hughes Jd'A, Keatinge JDH. The nourished millennium: how vegetables put global goals for healthy, balanced diets within reach. 24-26 Jan 2012, Chiang Mai, Thailand. In Holmer RJ, Linwattana G, Nath P, Keatinge $\mathrm{JDH}$, editors. ASEAN regional symposium on high value vegetables in Southeast Asia: production, supply and demand (SEAVEG 2012); 2013. pp 11-26, Shanhua, Taiwan: AVRDC

26. Johns T, Eyzaguirre PB. Biofortification, biodiversity and diet: a search for complementary applications against poverty and malnutrition. Food Policy. 2007;32(1):1-24.

27. Jones AD, Shrinivas A, Bezner-Kerr R. Farm production diversity is associated with greater household dietary diversity in Malawai: findings from nationally representative data. Food Policy. 2014:46:1-12.

28. Joshi PK, Gulati A, Birthal PS, Tewari L. Agriculture diversification in South Asia: patterns, determinants and policy implication. Econ Polit Wkly. 2004;39(24):2457-67

29. Joshi PK, Tewari L, Birthal PS. Diversification and its impact on smallholders: evidence from a study on vegetable production. Agric Econ Res Rev. 2006;19(2):219-36.

30. Kant A, Schatzkin A, Harris TB, Ziegel RG, Block G. Dietary diversity and subsequent mortality in the first national health and nutrition examination survey epidemiologic follow-up study. Am J Clin Nutr. 1993;57:434-40.

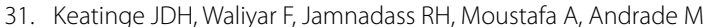
Drechsel $\mathrm{P}$, et al. Re-learning old lessons for the future of food: by bread alone no longer-diversifying diets with fruit and vegetables. Crop Sci. 2010;50:51-62.

32. Keatinge JDH, Yang R-Y, Hughes J, Easdown WJ, Holmer R. The importance of ensuring both food and nutritional security in the likely 
future attainment of the millennium development goals. Food Secur. 2011;3:491-501.

33. Keatinge JDH, Wang J-F, Dinssa FF, Ebert AW, Hughes J, Stoilova T, Nenguwo N, Dhillon NPS, Easdown WJ, Mavlyanova R, Tenkouano A, AfariSefa V, Yang R-Y, Srinivasan R, Holmer RJ, Luther G, Ho F-I, Shahabuddin A, Schreinemachers P, Iramu E, Tikai P, Dakuidreketi-Hickes A, Ravishankar M. Indigenous vegetables worldwide: their importance and future development. Acta Hortic. 2015;1102:1-20.

34. Keding GB. Linking nutrition security and agrobiodviersity: the importance of traditional vegetables for nutritional health of women in rural Tanzania, PhD thesis, Institute of Nutritional Sciences, Justus-LiebigUniversity Giessen. Göttingen, Germany: Cuvillier Verlag; 2010.

35. Keding GB,Weinberger K, Swai I, Mndiga H. Diversity, traits and use of traditional vegetables in Tanzania (Technical Bulletin No.40). Shanhua: AVRDC-The World Vegetable Center; 2007.

36. Keding GB, Msuya JM, Maass BL, Krawinkel MB. Relating dietary diversity and food variety scores to vegetable production and socio-economic status of women in rural Tanzania. Food Secur. 2012:4:129-40.

37. Kennedy GL, Pedro MR, Seghieri C, Nantel G, Brouwer I. Dietary diversity score is a useful indicator of micronutrient intake in non-breast-feeding Filipino children. J Nutr. 2007;137(2):472-7.

38. Leach V, Blandina K. Institutional analysis of nutrition in Tanzania, REPOA Special Paper 09.31, REPOA Research on Poverty Alleviation, Tanzania; 2009.

39. Lo Y-T, Chang Y-H, Lee M-S, Wahlqvist ML. Dietary diversity and food expenditure as indicators of food security in older Taiwanese. Appetite. 2012:58:180-7.

40. Lyson TA, Welsh R. The production function, crop diversity and the debate between conventional and sustainable agriculture. Rural Sociol. 1993;58(3):424-39.

41. Mazengo MC, Simell O, Lukmanji Z, Shirima R, Karvetti RL. Food consumption in rural and urban Tanzania. Acta Trop. 1997;68(3):313-26.

42. Meng ECH, Smale M, Bellon M, Grimanelli D. Definition and measurement of crop diversity for economic analysis. In: Smale M, editor. Chapter 2: farmers gene banks and crop breeding: economic analyses of diversity in wheat maize and rice. New York: Springer; 1998. p. 19-32.

43. Migotto M, Davis B, Caretto G, Beegle K. Measuring food security using respondents' perception of food consumption adequacy, WIDER Research Paper No. 2006/88, UNU-WIDER, United Nations University (UNU); 2006. www.wider.unu.edu/stc/repec/pdfs/rp2006/rp2006-88.pdf. Accessed 08 June 2013.

44. Nagarajan L, Melinda S, Paul G. Comparing farm and village-level determinants of millet diversity in marginal environments of India, Discussion Paper-139, International Food Policy Research Institute (IFPRI). Washington D.C.; 2005

45. Ohiokpehai O. Promoting the nutritional goodness of traditional food products. Pak J Nutr. 2003;2(4):267-70.

46. Ojiewo C, Tenkouano A, Hughes J, Keatinge JDH. Diversifying diets: using indigenous vegetables to improve profitability, nutrition and health in Africa. In: Fanzo J, Hunter D, Borelli T, Earthscan FM, editors. Diversifying food and diets: using agricultural biodiversity to improve nutrition and health. Abingdon: Routledge; 2013. p. 291-302.

47. Pellegrini L, Luca T. Crop diversification, dietary diversity and agricultura income: empirical evidence from eight developing countries. Presented in 54th annual conference, University of Bologna, 24-26 Oct; 2013. http:// www.siecon.org/online/wp-content/uploads/2013/09/Pellegrini-Tasciotti-crop-diversification.pdf Accessed 5 Mar 2014.

48. Romeo A, Meerman J, Demeke M, et al. Linking farm diversification to household diet diversification: evidence from a sample of Kenyan ultrapoor farmers. Food Secur. 2016;8:1069. doi:10.1007/s12571-016-0617-3.

49. Ruel MT. Operationalizing dietary diversity: a review of measurement issues and research priorities. J Nutr. 2003;133:3911S-26S.

50. Savy M, Martin-Prevel Y, Traissac P, Delpeuch F. Measuring dietary diversity in rural Burkina Faso: comparison of a 1-day and a 3-day dietary Recall. Public Health Nutr. 2007;10(1):71-8.

51. Settle W, Garba MH. Sustainable crop production intensification in the Senegal and Niger River basins of francophone West Africa. Int J Agric Sustain. 2011;9:171-85.

52. Shaxson L, Tauer LW. Intercropping and diversity: an economic analysis of cropping pattern on smallholder farms in Malawi. Exp Agric. 1992;28(02):211-28.
53. Sibhatu KT, Krishna W, Qaim M. Production diversity and dietary diversity in smallholder farm households. Proc Natl Acad Sci U S A. (2015);112(34):10657-10662. doi:10.1073/pnas.1510982112.

54. Simpson EH. Measurement of diversity. Nature. 1949;163:688.

55. Smale M, Moursi M, Birol E. Maize hybrids, diversity of diets and sources of vitamin A among Smallholder farmers in Zambia presented in the 4th international conference of the African Association of Agricultural Economists, Sept 22-25, 2013, Tunisia; 2013.

56. Smale M, Mourad M, Ekin B. How does adopting hybrid maize affect dietary diversity on family farm? Micro-evidence from Zambia. Food Policy. 2015;52:44-53.

57. Thompson B, Meerman J. Towards long-term nutrition security: the role of agriculture in dietary diversity, proceedings of the international symposium on food and nutrition security: food-based approaches for improving diets and raising levels of nutrition, Rome, FAO and Wallingford, UK, CABl; 2010.

58. Thorne-Lyman AL, Valpiani N, Sun K, Semba RD, Klotz CL, Kraemer K, et al. Household dietary diversity and food expenditures are closely linked in rural Bangladesh, increasing the risk of malnutrition due to the financial crisis. J Nutr. 2009;140(1):1825-85.

59. Torheim LE, Ouattara F, Diarra MM, Thiam FD, Barikmo I, Hatloy A, Oshug A. Nutrient adequacy and dietary diversity in rural Mali: association and determinants. Eur J Clin Nutr. 2004;58(4):594-604.

60. Torres-Reyna O (2007). Linear Regression using Stata. Data and statistical services, Princeton University. Retrieved from https://www.princeton. edu/ otorres/Regression101.pdf. Accessed 25 Dec 2016.

61. Underwood RA. Overcoming micronutrient deficiencies in developing countries: Is there a role for agriculture? Food Nutr Bull. 2000;21(4):356-60.

62. Uusiku NP, Oelofse A, Duodu KG, Bester MJ, Faber M. Nutritional value of leafy vegetables of sub-Saharan Africa and their potential contribution to human health: a review. J Food Compos Anal. 2010;23:499-509.

63. Walker T, Tschirley D, Low J, Tanque M, Boughton D, Payongayong E, Weber M. Determinants of rural Income in Mozambique in 2001-2002. MINAG/DE/DAP Research Report No. 57E. Maputo, Mozambique: MINAG; 2004. www.aec.msu.edu/fs2/mozambique/wps57e.pdf. Accessed 5 Jan 2014.

64. Weinberger K. Micronutrient intake and labor productivity: evidence from a consumption and income survey among Indian agricultural labours. Outlook Agric. 2004;33(4):225-60.

65. Weinberger K, Swai I. Consumption of traditional vegetables in central and northeastern Tanzania. Ecol Food Nutr. 2006:45:87-103.

66. West CE, Pepping F, Temalilwa CR. The composition of foods commonly eaten in east Africa, Research Report, Department of Human Nutrition, Technical Centre Agricultural \& Rural Coop. (ACP-EEC Lome Convention) and ECSA Food \& Nutrition Coop. Wageningen Agricultural University; 1998.

67. Yang R-Y, Fischer S, Hanson PM, Keatinge JDH. Mapping nutritional values of indigenous vegetables in Africa. In: Juliani HR, Simon J, Ho CT, editors. African natural plant products II: Discoveries and challenges in chemistry, health and nutrition, vol. II. Washington D.C: American Chemical Society; 2013. p. 231-54.

\section{Submit your next manuscript to BioMed Central and we will help you at every step:}

- We accept pre-submission inquiries

- Our selector tool helps you to find the most relevant journal

- We provide round the clock customer support

- Convenient online submission

- Thorough peer review

- Inclusion in PubMed and all major indexing services

- Maximum visibility for your research

Submit your manuscript at www.biomedcentral.com/submit
BioMed Central 